\title{
Multi-scale assessment of metal contamination in residential soil and soil fauna: A case study in the Baltimore-Washington metropolitan region, USA
}

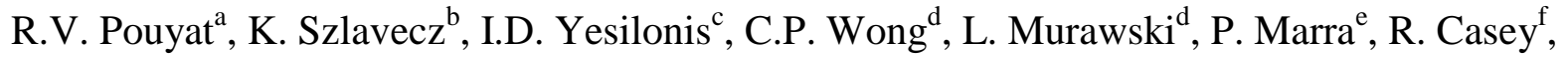
and S. Lev ${ }^{f}$

${ }^{\mathrm{a} U S D A}$ Forest Service, 1400 Independence Ave., SW, Washington, DC 20250-1112

bJohns Hopkins University, Department of Earth and Planetary Sciences, Baltimore, MD, 21218

${ }^{c}$ USDA Forest Service, Northern Research Station, University of Maryland Baltimore County, Baltimore, MD 21227

${ }^{\mathrm{d}}$ Cary Institute of Ecosystem Studies, Millbrook, NY, 12545

${ }^{\mathrm{e}}$ Migratory Bird Center, Smithsonian Institute, Washington, DC 20008

${ }^{\mathrm{f}}$ Urban Environmental Biogeochemistry Laboratory, Towson University, Towson, MD 21252

Corresponding author: Richard V. Pouyat (tel: 001703605 5286; fax: 001703605 5133;

email: rpouyat@fs.fed.us)

Number of words in text: 6900; Number of Figures: 6; Number of Tables: 3

Running title: Residential Soil Metals

Keywords: earthworms, heavy metals, isopods, soil, urban, urbanization gradient

Formatted for Landscape and Urban Planning 
2 Urban landscapes are conspicuously contaminated by trace metals and thus pose a potential

3 health risk to people and wildlife (Mielke 1999; Wong, Li, \& Thornton 2006; Luo, Yu, Zhu, \&

$4 \quad$ Li 2012). Although many studies have demonstrated that trace metals accumulate in soils of

5 urban landscapes, less is known about their spatial distribution at finer scales (Schwarz, Pickett,

6 Lathrop, Weathers, Pouyat, \& Cadenasso 2012) and potential for accumulating into soil fauna

7 and the animals that feed on these organisms (Roux \& Marra 2007). Metal accumulations in

8 urban soils have been associated with roadside environments and vehicular emissions (Manta,

9 Angelone, Bellanca, Neri, \& Sprovieri 2002; Zhang 2006; Werkenthin, Kluge, \& Wessolek

10 2014), interior and exterior paint (Trippler, Schmitt, \& Lund 1988), stack emissions (Govil,

11 Reddy, \& Krishna 2001; Walsh et al. 2001; Kaminski \& Landsberger 2000), management inputs

12 (Russell-Anelli, Bryant, \& Galbraith 1999), distance from roads (Wang, Ren, Liu, Yu, \& Zhang

13 2006; Yesilonis, Pouyat, \& Neerchal 2008; Schwarz et al. 2012), land use (Xia, Chen, Liu, \& Liu

14 2011; Mao, Huang, Ma, \& Sun 2014), and age of structures (Schwarz et al. 2012; Stewart,

15 Farver, Gorsevski, \& Miner 2014). The spatial pattern resulting from these factors is dependent

16 on characteristics of the source such as whether the metal was emitted from a point or non-point

17 source, the height of emission, and the particle size fraction of the pollutant (Cook \& Ni 2007).

Lead $(\mathrm{Pb})$ for example has been emitted into the environment as a gasoline additive and in paint and has over time accumulated in soils. In the United States, both uses have been

20 banned through policy actions for more than 30 years, but nonetheless, the ability of $\mathrm{Pb}$ and other

21 metals to persist in the environment has resulted in a distinct spatial pattern of accumulation in

22 soil and riparian sediments (e.g., Bain, Yesilonis, \& Pouyat 2010; Schwarz et al. 2012; Datko-

23 Williams, Wilkie, \& Richmond-Bryant 2014). Given the aforementioned factors, the resultant 
24 spatial pattern of $\mathrm{Pb}$ or other trace metals in urban soils should, in part, be determined by the 25 amount and length of exposure to emissions. For example, patterns differ because of the age of 26 the structure (older structures have been exposed to emitted $\mathrm{Pb}$ for a longer duration and are 27 more likely to have $\mathrm{Pb}$ based paint), the nature of the emitting source, such as the juxtaposition to a road and the volume of traffic on that road, and how far from the source the aerosols and 29 particulates have been dispersed.

In a review of the literature, Yesilonis et al. (2008) found that globally, urban soils consistently accumulated above background levels of $\mathrm{Pb}$, copper $(\mathrm{Cu})$, and zinc $(\mathrm{Zn})$. The authors associated this relationship with automobile usage, specifically tire wear (Zn), brake and radiator wear $(\mathrm{Cu})$, and the accumulation of $\mathrm{Pb}$ from historic use of leaded gasoline and paint. Moreover, due to the ability of soil to chemically or physical immobilize these metals, soils have the capacity to accumulate them (Yong, Mohamed, \& Warkentin 1992). In addition to $\mathrm{Pb}, \mathrm{Cu}$, and $\mathrm{Zn}$, other metals including nickel $(\mathrm{Ni})$, arsenic (As), cadmium $(\mathrm{Cd})$, and chromium $(\mathrm{Cr})$ have

37 been reported to accumulate in urban environments (Kay, Arnold, Cannon, \& Graham 2008; Odewande \& Abimbola 2008; Zheng, Chen, \& He 2008). Like Pb, Cu, and Zn, the presence of $\mathrm{Ni}, \mathrm{Cd}$, and $\mathrm{Cr}$ in the environment can be related to automobile use (van Bohemen \& Janssen van de Laak 2003) but also industrial sources (Rawlins, Lark, O’Donnell, Tie, \& Lister 2005), while As has been introduced into residential areas as a wood preservative (Townsend, Solo-Gabriele, 42 Tolaymat, Stook, \& Hosein 2003). Since most of the emission sources for trace metals are associated with urban land uses, there have been a number of studies examining the relationship between metal concentrations in remnant patches, such as a forest patch, with distance to the urban core or some metric of urban 46 land use, i.e., an urbanization gradient. For example, Pouyat, Yesilonis, Szlavecz, Csuzdi, 
47 Hornung, Korsos, Russell-Anelli, \& Giorgio (2008) showed evidence of a depositional pattern of

48 metals in forest soils along urbanization gradients in the New York City, Baltimore, and

49 Budapest metropolitan areas. The authors found a two to three-fold increase in contents of $\mathrm{Pb}$,

$50 \mathrm{Cu}$, and $\mathrm{Ni}$ in urban forest remnants compared to suburban and rural counterparts. A similar

51 pattern but with greater differences was found by Inman \& Parker (1978) in the Chicago, IL

52 metropolitan area, where levels of heavy metals were more than five times higher in urban than

53 in rural forest patches. Other urbanization gradient studies have shown a similar pattern

54 (Watmough, Hutchinson, \& Sager 1998; Sawicka-Kapusta, Zakrzewska, Bajorek, \& Gdula-

55 Argasinska 2003), although smaller cities or cities having more compact development patterns

56 exhibited less of a difference between urban and rural forest soils (Pavao-Zuckerman 2003;

57 Pouyat et al. 2008; Carreiro, Pouyat, \& Tripler 2009). In all of these studies, regional relationships were established by sampling relatively undisturbed remnant patches and did not

59 include more disturbed or managed soils associated with residential land use, which are the soils

60 most implicated with metal exposure to humans, e.g., $\mathrm{Pb}$ in children (Mielke, Gonzales, Powell,

$61 \&$ Mielke 2008). For urban soils in the United States, a recent review of the literature showed

62 that for all studies considered, soils in urban centers had higher $\mathrm{Pb}$ concentrations than in

63 suburban areas, with the exception of New Orleans (Datko-Williams et al. 2014).

Besides human exposure, the accumulation of trace metals in urban soils can also affect

65 soil fauna. Indeed, soil invertebrates are often used as indicators of pollutant levels (Dallinger 1994; Nahmani \& Lavelle 2002), although interpreting the results can be challenging due to the

67 multiple factors involved (Beyer \& Cromartie 1987; Nahmani, Hodson, \& Black 2007). Soil 
Scharenberg \& Ebeling 1996, Kamitani \& Kameko 2007). For instance, earthworms are less

71 mobile and consume a mixture of soil and detritus while isopods and millipedes are more active

72 and feed mainly on plant detritus. An additional effect of metals in soil fauna is the potential for

73 the bioconcentration of metals up the food chain (Hopkin \& Martin 1985; Raczuk \& Pokora

74 2008). Soil organisms are a primary food source for many invertebrate and vertebrate predators,

75 and thus in heavily contaminated areas there is an increased risk of secondary poisoning

76 (Spurgeon \& Hopkin 1996; Reinecke, Reinecke, Musibono, \& Chapman 2000; Maerz, Karuzas,

77 Madison, \& Blossey 2005). For example, earthworms are an especially important component of

78 the diet of ground feeding birds due to their high energy and nutrition content (Török \& Ludvig 79 1988).

Because soil fauna can accumulate trace metals from soil and relatively few studies have

81 compared metal concentrations of residential soils at multiple scales (residential yard to

82 metropolitan region), the objectives of this study were threefold: 1) compare metal

83 concentrations of soils in residential yards that varied in age from inner urban to rural areas in

84 the Baltimore-Washington metropolitan area; 2) compare metal concentrations of soils in patch

85 types that differ in location and soil cover within individual residential yards; and 3) correlate

86 soil metal concentrations with the body burden of metals in earthworms (Annelida:Oligochaeta)

87 and terrestrial isopods (Crustacea:Isopoda), both of which are potential food sources for several

88 bird species in the region (Roux \& Marra 2007). In the first case, a comparison of soil metal

89 concentrations of residences along an urbanization gradient will reflect, in part, the age of the

90 structures (e.g., before and after policy changes in $\mathrm{Pb}$ additives to paint and gasoline) and the

91 effect of vehicular traffic occurring in residential areas in the Baltimore-Washington

92 metropolitan area. In the second and third cases, a comparison of metals in soils, earthworms, 
93 and isopods associated with five yard patch types comprised of either lawn (front and back) or

94 planting beds (building foundation, yard or road) along an urbanization gradient will reflect

95 spatial patterns at regional and lot, or yard, scales.

For the first and second objectives, we expected metal concentrations would be greater in

97 more densely populated areas due to higher emissions, and that soils associated with patch types within yards that were closer to roads and adjacent to house foundations would have greater

99 accumulations of metals than in the front or back lawns, particularly for $\mathrm{Pb}, \mathrm{Cu}$, and $\mathrm{Zn}$.

100 Moreover, we expected these differences to be magnified by the time of exposure (i.e., age of

101 structure). For objective 3, we expected that the body burdens of earthworms would reflect

102 concentrations of metals in the soils they were collected from, while body burdens of soil

103 isopods would reflect metal concentrations to a lesser degree because of their greater mobility 104 and different diet.

\section{Methods}

\subsection{Study Area}

Baltimore City is a historically industrial city located on the Chesapeake Bay in the Mid-Atlantic region of the USA $\left(39^{\circ} 17^{\prime} 11^{\prime \prime} \mathrm{N}, 76^{\circ} 36^{\prime} 54^{\prime \prime} \mathrm{W}\right)$. During the last several decades, Baltimore has undergone a significant loss in population. Between 1950 and 2000, the city's population fell

111 from 949,708 (http://www.census.gov/population/www/documentation/twps0027/tab18.txt,

112 verified 1/28/2015) to 651,154 (http://censtats.census.gov/data/MD/05024510.pdf, verified

113 1/28/2015). The depopulation of Baltimore has resulted in a large number of residential housing 114 vacancies and vacant lots. Most of the housing stock in Baltimore was built prior to 1950 in 
115 contrast to the surrounding Baltimore County area which experienced a substantial increase in 116 housing growth after 1950 . Only $60 \mathrm{~km}$ from Baltimore, Washington, DC is located near the 117 Chesapeake Bay in the Mid-Atlantic region of the USA on the Potomac River, a tributary to the 118 Bay. Unlike Baltimore, Washington has not had a history of heavy industrial use or a loss of 119 population in the previous 50 years.

121 with average annual air temperatures ranging from $14.5^{\circ} \mathrm{C}$ in the inner urban areas to $12.8^{\circ} \mathrm{C}$ in 122 the surrounding rural areas. This difference in air temperature in the metropolitan area is 123 attributed to the heat island effect (Brazel, Selover, Vose, \& Heisler 2000). Precipitation is 124 distributed evenly throughout the year for the entire study area and ranges from an annual 125 average of $106.8 \mathrm{~cm}$ in Baltimore and Washington to $103.1 \mathrm{~cm}$ in the surrounding metropolitan 126 area (NOAA, http://www.nws.noaa.gov/climate/local_data.php?wfo=lwx, verified on $1271 / 28 / 2015)$

129 Bay between two physiographic provinces: the Piedmont Plateau and the Atlantic Coastal Plain. 130 Most of the metropolitan area is characterized by nearly level to gently rolling uplands dissected 131 by narrow stream valleys. Portions of the Piedmont Plateau in the region are underlain by mafic 132 and ultramafic rock types (Crowley \& Rhinhardt 1979). The Coastal Plain is underlain by much 133 younger, poorly consolidated sediments. Soils in the Coastal Plain are typically very deep, 134 somewhat excessively drained and well-drained upland soils that are underlain by either sandy or 135 gravelly sediments or unstable clayey sediment. The dominant coastal plain soils in the 136 metropolitan area consist of Typic Hapludults. Soils in the Piedmont Plateau of the Baltimore137 Washington metropolitan area are very deep, moderately sloping, well-drained upland soils that 
138 are underlain by semi-basic or mixed basic and acidic rocks (NRCS 1976, 1998). The dominant 139 piedmont soils in the metropolitan area consist of Ultic Hapludalfs. Highly disturbed soils and 140 impervious surfaces make up more than $60 \%$ and $41 \%$ of the land area of Baltimore and 141 Washington, DC, respectively (Pouyat, Groffman, Yesilonis, \& Hernandez 2002; Nowak \& 142 Greenfield 2009).

All residences that were sampled were associated with Neighborhood Nestwatch, a

144 citizen science program operated through the Smithsonian Migratory Bird Center at the National 145 Zoo in Washington, DC

146 (http://nationalzoo.si.edu/scbi/MigratoryBirds/Research/Neighborhood_Nestwatch/, verified on 147 1/28/2015). Nestwatch program participants help monitor nests and bird sightings in their own 148 yards (Evans, Abrams, Reitsma, Roux, Salmonsen, \& Marra 2005). In order to participate in the 149 Nestwatch program, residents must live within a 75-mile radius of Washington, DC. As of 2010, 150 there were 220 participating sites. The residences selected for our study represent a diversity of 151 the Nestwatch participants due to the different degrees of urbanization sampled. The urban-rural 152 comparisons of residential land use encompassed the Washington, DC and Baltimore, MD 153 metropolitan areas and extended to Caroline and Carroll County, MD. The urban-rural 154 comparison of residential yards consisted of four land-use types defined by population density (\# 155 of individuals per square mile): 1) inner-urban $(>8,000) ; 2)$ outer-urban $(7,999-2,000) ; 3)$ 156 suburban (1999 - 300); and 4) rural (<299) (U.S. Census Bureau 2000). The total number of 157 residential yards sampled included 8 inner-urban (IU), 4 outer-urban (OU), 4 suburban (S), and 7 158 rural (R) for a total of 23 residential yards (Fig. 1). These yards were randomly selected within 159 the Nestwatch project. The residences were far enough apart that independence between them 160 could be assumed. 
Each yard was subdivided into patches delineated by management, cover, and location

162

163

164

165

166

167

168

169

170

171

172 from roads into back yards.

173

174

175

176

177

178

179

180

181

182

183

\subsection{Soil Sampling and Analysis}

with respect to the foundation of the house and the nearest road, the two areas on residential lots where trace metals have been shown to accumulate in soil (Mielke 1999; Yesilonis et al. 2008;

Schwarz et al. 2012). In addition, front and back lawns were sampled separately because of likelihood of differences in exposure to emission sources, use, and management. The resultant delineations included front lawn (FL), back lawn (BL), roadside bed (RB), yard bed (YB), and foundation bed (FB) patch types (Fig. 2). House, or structural, age and landscaping practices were recorded for each residence. Residences were subsequently divided into two age categories: pre - and post - 1940 homes (leaded gasoline began use in the 1930s and commuter traffic increased after 1940 in the metropolitan area). In all cases, the structures were no taller than three floors and thus eddy air flow patterns had potential to transport particles emanating

In each yard patch type (FL, BL, RB, YB, and FB), 15 soil cores from a depth of 0-10 cm were collected, and thatch and other fabric material were removed prior to placing cores in a paper bag. These 15 cores were taken in areas that most represented the yard patches. Soil cores from each bag were air-dried, ground, and sieved through a 2-mm mesh sieve. A subsample was ashed in a muffle oven for four hours at $450^{\circ} \mathrm{C}$ to determine ash-free dried weight. Additional subsamples were digested at the Baltimore Ecosystem Study/University of Maryland Baltimore County Laboratory using a nitric acid extraction (modified EPA method 3050B). Soil extracts were analyzed at Towson University in Maryland to determine acid soluble extractable As, $\mathrm{Cu}$, $\mathrm{Cr}, \mathrm{Ni}, \mathrm{Pb}$, and $\mathrm{Zn}$ using an Inductively Coupled Plasma Mass Spectrophotometer (ICP-MS). All samples were spiked with $1 \mathrm{ug} / \mathrm{L}$ Indium internal standard solution to monitor and correct for 
184 instrumental drift and matrix effects. Each batch of 20 samples was typically run with at least 185 one NIST Standard Reference Material (SRM) to monitor recovery and one duplicate sample to monitor reproducibility. All SRMs for the data reported were within $85-105 \%$ recovery, and

187 duplicate samples did not deviate by more than $10 \%$ from the mean measured value. Elemental 188 data are presented as a concentration per dry weight of soil $\left(\mathrm{mg} \mathrm{kg}^{-1}\right)$.

\subsection{Earthworm and Isopod Sampling}

190

In all 23 residences, the $\mathrm{RB}, \mathrm{YB}$, and $\mathrm{FB}$ planting beds were sampled for earthworm abundance using a $25 \times 25-\mathrm{cm}$ quadrat treated with $8 \mathrm{~L}$ of $0.05 \%$ formalin solution (Raw 1959). The quadrant was placed in a representative area for that patch. Collected earthworms were killed in $70 \%$ ethanol and immediately placed in $4 \%$ formalin solution. Initial attempts to sample FL and BL patch types for earthworms resulted in only a few individuals, and therefore we discontinued sampling for earthworms in these patch types. In addition, about $80 \%$ of the total sample was Lumbricus sp. juveniles or Lumbricidae juveniles and therefore only lumbricid earthworms were used in the tissue analysis. At each site, soil moisture (Dynamax $\mathrm{TH}_{2} \mathrm{O}$ soil moisture probe), soil temperature (Taylor Precision TruTemp Thermometer), leaf litter depth, slope, and other site characteristics were recorded. In addition, all isopods visibly present within a thirty-minute sampling period were collected from road, foundation and yard bed patch types.

In the laboratory, the collected earthworms (total of 338) and isopods (more than 500) were dried at $70^{\circ} \mathrm{C}$ to a constant weight. A randomly chosen subsample of isopods $(\mathrm{n}=38)$ and adult earthworms $(n=17)$ were selected for analysis. Each earthworm was dissected, and guts were removed to examine tissue metal content. Samples less than $0.5 \mathrm{~g}$ dry weight were digested directly. If the total sample mass exceeded $0.5 \mathrm{~g}$, tissues were homogenized using a Teflon 
mortar and acid-washed glass pestle on a powered drive. A subsample of the homogenized tissue was then digested. Invertebrates were digested at Towson University with $6 \mathrm{M}$ trace metal grade $\mathrm{HNO}_{3}$ in Teflon vessels at $150^{\circ} \mathrm{C}$ overnight. The solution was then evaporated to dryness and digestion continued with $3 \mathrm{~mL}$ of $30 \%$ high purity $\mathrm{H}_{2} \mathrm{O}_{2}$ (Ultrex II grade, J.T. Baker). The digestate was then diluted with $0.2 \mathrm{M}$ trace metal grade $\mathrm{HNO}_{3}$ for analysis.

\subsection{Statistical Analysis}

\subsubsection{Soil Data}

As an exploratory and data reduction technique, the elemental data were first submitted to a principal component analysis (PCA) factoring in a correlation matrix using the SAS package (SAS Institute, version 8.0 2003). A PCA can take several soil properties and express them in terms of a few common components (Pielou 1984). The first principal component (PC1) explains the maximum possible variance of the dataset, the second component (PC2) explains the maximum variance subject to being uncorrelated with PC1, the third component (PC3) explains the maximum variance subject to being uncorrelated with PC1 and PC2, and so on (Usher 1976). We used a scree plot along with the eigenvalues to determine the number of principal components that were kept. We ran separate PCA runs using concentration data $\left(\mathrm{mg} \mathrm{kg}^{-1}\right) \mathrm{of} \mathrm{Cd}_{\text {, }}$ $\mathrm{Cu}, \mathrm{Co}, \mathrm{Cr}, \mathrm{Fe}, \mathrm{Mn}, \mathrm{Ni}, \mathrm{Pb}, \mathrm{Ti}, \mathrm{V}$, and $\mathrm{Z}$ for lawn (FL and BL) and planting bed types (RB, FB, and YB).

To test for differences among residences in IU, OU, S, and R land-use types, means for individual soil properties and the principle components resulting from the PCA (PC1, PC2, and PC3) were analyzed using a restricted likelihood estimation technique in SAS Proc Mixed and using GT2 Hochbergs pair-wise comparisons. Residences were far enough apart such that no 
228 spatial correlation was considered. Land-use type was a fixed effect, and there were no random

229 effects (SAS Institute, 2003). The effect of land use on soil concentrations of the residences

230 sampled along the urban-rural gradient was analyzed by Proc Mixed. Separate Proc Mixed tests

231 were run for the lawn (FL and BL) and planting bed (RB, FB, and YB) patch types because we

232 needed to keep the soil samples separate (for correlating with soil organism body burdens) and

233 because of large differences in surface area between the yard patch types. The 15 subsamples

234 were not individually considered in the statistical analysis because they were composited during

235 field collection. In addition, residences were subdivided by age structure (pre - and post - 1940)

236 irrespective of land-use type. A mixed model was used to test for differences in log-transformed

237 elemental concentrations between pre - and post - 1940 structures. Since the number of

238 residences sampled per population category and structure age was unequal, Hochberg's Method

239 for unequal sample sizes was used to determine significant differences between means. Soil

240 variables were $\log _{10}$ transformed to stabilize the variance of individual properties where

241 necessary.

242 2.4.2. Body Burden Comparisons

243 Body burden metal concentrations were correlated with soil metal data from the same yard patch

244 type the organism was collected from using Pearson correlation ( $n=17$ for earthworms and $n=38$

245 for isopods). In addition, blood concentrations of $\mathrm{Pb}$ were available for several species of birds

246 in 12 of the residences sampled in this study (Roux \& Marra 2007). We took advantage of this

247 overlap to conduct a post-hoc analysis correlating $\mathrm{Pb}$ concentrations in soil, earthworm, and

248 isopod bodies with bird blood concentrations of $\mathrm{Pb}$ in the commonly sampled residences using

$249 \log _{10}$ transformed data in a Pearson correlation. 


\section{3. Results}

252 Measured concentrations of trace metals varied widely in this study. The distribution of all

253 metals is right-skewed with the mass of the distribution concentrated to the left, i.e. low

254 elemental concentration values (Table 1). Even with skewed distributions, contamination of at

255 least one metal has occurred for many of the yards sampled in this study. For example, at least

$25620 \%$ of the patches sampled had $\mathrm{Pb}$ concentrations of $93 \mathrm{mg} \mathrm{kg}^{-1}$ or greater, which is slightly

257 greater than the guidelines for soil $\mathrm{Pb}$ in the Netherlands, or $90 \mathrm{mg} \mathrm{kg}^{-1}$ (Table 1). In fact, at the $25880^{\text {th }}$ percentile, $\mathrm{Cu}, \mathrm{Ni}, \mathrm{Pb}$, and $\mathrm{Zn}$ had concentrations above-background levels for all of the 259 yard patches sampled (Table 1).

\subsection{Principal Component Analysis (PCA)}

261 A clear relationship was discernible in the PCA for both lawn (front and back) and planting bed 262 (road, foundation, and yard) soils among land-use types and age categories in the Baltimore263 Washington metropolitan area (Figs 2a and 2b). For the lawn soils, $80 \%$ of the variation was 264 explained by the first three components of the PCA, with PC1 accounting for $51 \%$ of the 265 variation. For the planting bed soils, a slightly lower percentage of the variance (77\%) was 266 explained by the first three components of the PCA, with PC1 accounting for $44 \%$ of the 267 variation. For both soils, positive loadings of $\mathrm{PC} 1$ corresponded to $\mathrm{Cd}, \mathrm{Cu}, \mathrm{Pb}$, and $\mathrm{Zn}$ with the 268 addition of $\mathrm{Cr}$ for the lawn soils (Figs $2 \mathrm{a}$ and $2 \mathrm{~b}$ ). Likewise, the second principal component 269 (PC2) was positively associated with $\mathrm{Ni}$ and Se for both the lawn and planting bed soils.

270 Inspection of the scatter plots for the first two components (PC1 and PC2) with symbols 271 representing land-use type showed a clustering of IU residences to the right of the origin 
272 (positive loadings of $\mathrm{PC} 1$ or higher concentrations of $\mathrm{Cd}, \mathrm{Cu}, \mathrm{Pb}$, and $\mathrm{Zn}$ ) while $\mathrm{R}$ residences

273 clustered to the left (negative loadings) for both lawn and planting bed soils. We interpret the

274 distribution of lawn and planting bed samples along PC1 to represent an urbanization gradient.

275 The distribution of sample sites along PC2 is less clear. For the lawn samples, the IU soils

276 clustered below the origin (negative loadings, or elevated concentrations of $\mathrm{Ni}$ and $\mathrm{Se}$ ) and $\mathrm{R}$

277 soils tended to have positive loadings with respect to PC2 (Fig. 2a), whereas the planting bed

278 soils did not exhibit a discernible pattern with respect to PC2 (Fig. 2b).

279

280

281

282

283

284

285 area.

286

287 Consistent with the PCA, a similar relationship for both lawn (front and back) and bed (road,

288 foundation, and yard) soils was shown in statistical comparisons among land-use categories (Fig

289 4). Lawn soil concentrations of $\mathrm{As}, \mathrm{Cd}$, and $\mathrm{Pb}$ varied significantly $(\mathrm{P}<0.05)$ among the land-

290 use categories (Fig. 4a), as did PC1 (results not shown). Differences between IU and R lawn

291 soils varied almost eight-fold for $\mathrm{Pb}$, three-fold for $\mathrm{Cd}$, and more than two-fold for As. A post-

292 hoc test showed that for all three metals, IU exhibited higher concentrations than in lawn soils of

$293 \mathrm{R}$ residences. 
Bed soil patches exhibited a slightly stronger relationship than lawn soils across the 295 urban-rural gradient (Fig. 4b). In addition to $\mathrm{Cd}$ and $\mathrm{Pb}$, the yard patch soil comparisons also 296 differed statistically for $\mathrm{Cu}$ and $\mathrm{Zn}$ (Fig. 4b) as did PC1 (results not shown). Differences

297 between IU and $\mathrm{R}$ bed patch soils varied almost ten-fold for $\mathrm{Pb}$ and roughly five-fold for $\mathrm{Cd}, \mathrm{Cu}$, 298 and Zn. A post-hoc test showed that for all 4 metals, the IU statistically differed from the R 299 land-use type (Fig. 4b).

\subsection{Structure Age}

301 A similar relationship for both lawn and bed soils was shown in comparisons between pre - and 302 post - 1940 structures (Fig. 5). Lawn soil concentrations of $\mathrm{Zn}$ and $\mathrm{Pb}$ varied statistically $(\mathrm{P}<$ 303 0.05) between structure ages (Fig. 5a), as did PC2 (results not shown), which primarily related to 304 positive loadings of Se and Ni (Fig. 3a). Differences between pre - and post - 1940 structures

305 for lawn soils were more than five-fold for $\mathrm{Pb}$ and two-fold for $\mathrm{Zn}$. A post-hoc mean separation 306 test showed that for $\mathrm{Pb}$ and $\mathrm{Zn}$, the pre - 1940 structures exhibited statistically higher 307 concentrations than in lawn soils of post - 1940 structures (Fig. 5a).

309 age (Fig. 5b). In the addition to $\mathrm{Pb}$ and $\mathrm{Zn}$, the bed patch soil comparisons also differed 310 statistically for Cd and Ca (Fig. 5b), as did PC1 and PC3 (results not shown). Differences 311 between Pre and Post 1940 bed patch soils varied almost ten-fold for $\mathrm{Pb}$ and roughly five-fold 312 for Cd and Zn. A post-hoc test showed that for all 3 metals the Pre and Post 1940 age types 313 statistically differed from each other (Fig. 5b). 
315 There were no statistical differences $(\mathrm{P}<0.05)$ among the five yard patch types for all land-use

316 types and the land-use types that we expected to be the most polluted, i.e., OU and IU (Table 2).

317 However, FB and $\mathrm{YB} \mathrm{Pb}$ concentrations were up to 5-fold greater than FL and BL

318 concentrations.

\subsection{Earthworm and Isopod Body Burdens}

320 Earthworm adults were dominated by L. rubellus and L. terrestris. A few juvenile Amynthas sp.

321 (Megascolecidae), and three Diplocardia sp. (Acanthodrilidae) individuals were caught across all

322 sampling units. Most of the isopods caught were either Trachelipus rathkii or Armadillidium

323 nasatum. Both are non-native, synanthropic, invasive species.

Body burden relationships between soil fauna and soil metal concentrations differed

325 between earthworms and isopods (Table 3). Isopod burdens were, in general, directly related to soil metal concentrations ( $\mathrm{As}, \mathrm{Cr}, \mathrm{Ni}, \mathrm{Pb}$, and $\mathrm{Zn}$ ) compared to earthworm burdens, which were

327 only statistically related to soil $\mathrm{Pb}$ concentrations at $\mathrm{P}<0.03, \mathrm{r}=0.52$. Of the metals associated

328 with isopod body burdens, soil concentration of $\mathrm{Pb}$ explained more than $70 \%$ of the variation.

329 All of the remaining metals that were statistically related at $\mathrm{P}<0.05$ explained between $47-59 \%$

330 of the variation in isopod body burdens for $\mathrm{As}, \mathrm{Cr}, \mathrm{Ni}$, and $\mathrm{Zn}$, respectively (Table 3).

Relationships between soil, body burden, and bird blood metal concentrations at the 332 commonly sampled locations are mixed, probably due to low sample sizes; still, the results 333 suggest that $\mathrm{Pb}$ soil contamination can potentially lead to both higher body burden and bird 334 blood concentrations (Figure 6a and 6b). For earthworm burden and bird blood levels of $\mathrm{Pb}$, $33578 \%$ of the variation is explained at $\mathrm{P}=0.013$ (Fig. 6a). By contrast, earthworm burden to soil $\mathrm{Pb}$ 336 concentrations were not significant for this subset of residences $(r=0.50, P=0.17)$. However, for 
337 the same residences, bird blood and soil $\mathrm{Pb}$ concentrations were significantly related $(\mathrm{r}=0.66$,

$338 \mathrm{P}=0.05)$. Similar relationships were found with the isopod body burden, bird blood, and soil $\mathrm{Pb}$

339 concentrations at a subset of residences where bird blood and isopod burdens of $\mathrm{Pb}$ were

340 measured (Fig. 6b). For isopod burden and bird blood levels of $\mathrm{Pb}$, the Pearson correlation was

341 not statistically significant $(\mathrm{P}=0.19)$. However, soil $\mathrm{Pb}$ concentrations were statistically related to

342 isopod body burdens $(\mathrm{r}=0.83, \mathrm{P}<0.0001)$ as well as bird blood and soil $\mathrm{Pb}$ concentrations

$343(\mathrm{r}=0.58, \mathrm{P}=0.01)$.

345 4. Discussions

346

\subsection{Soil Metal Concentrations}

347 Overall OU, IU, S land-use types had higher soil concentrations of $\mathrm{Pb}, \mathrm{Cu}, \mathrm{Zn}, \mathrm{As}$, and $\mathrm{Cd}$, than 348 rural residential soils (Fig. 4). The accumulation of $\mathrm{Pb}, \mathrm{Cu}, \mathrm{Zn}, \mathrm{Cd}$, and $\mathrm{Cr}$ in particular 349 corresponded to urban environments, which we expect is primarily the result of vehicle pollutant 350 sources (van Bohemen \& Janssen van de Laak 2003; Councell, Duckenfield, Landa, \& Callender 351 2004; Hjortenkrans et al. 2006). Our expectation that $\mathrm{Cu}, \mathrm{Pb}$, and $\mathrm{Zn}$ would be higher in $\mathrm{IU}$ than 352 rural land-use types was thus supported; however, the differences found with $\mathrm{Cd}$ and $\mathrm{Cr}$ was not 353 expected for the residential soils included in this study. Despite our expectations, studies have 354 found soils contaminated with $\mathrm{Cd}$ and $\mathrm{Cr}$ in urban areas, and in both cases, contamination was 355 associated with vehicular sources at a city scale (Steiner et al. 2007; Xia et al. 2011). Indeed, Cd 356 has been associated with tire wear while $\mathrm{Cr}$ is used for a number of parts found on vehicles (van 357 Bohemen \& Janssen van de Laak 2003). 
Overall, the patterns for metal concentrations found in residential soils in the

359 Washington-Baltimore area (Table 1) were comparable to patterns found in forest patches more remote from roads along urban-rural gradients in Baltimore and New York (Pouyat et al. 2008),

361 but with residential soils measured in this study generally having higher concentrations than

362 those found in forest soils. In comparison to Pouyat, Yesilonis, Russell-Anelli, \& Neerchal

363 (2007), where in Baltimore only IU residential land use types were sampled $(0-10 \mathrm{~cm} \mathrm{depth}), \mathrm{Cu}$

$364\left(43 \pm 3.3 \mathrm{mg} \mathrm{kg}^{-1}\right)$ and $\mathrm{Zn}\left(145 \pm 21.0 \mathrm{mg} \mathrm{kg}^{-1}\right)$ concentrations $\left(\mathrm{mg} \mathrm{kg}^{-1}\right)$ generally fell within the

365 range of values measured in this study, while $\mathrm{Pb}\left(340 \pm 118 \mathrm{mg} \mathrm{kg}^{-1}\right)$ concentrations appeared to 366 be slightly higher.

Concentrations for $\mathrm{Pb}$ found in this study are noticeably lower than values (mean $363 \mathrm{mg}$

$368 \mathrm{~kg}^{-1}$ ) reported in Baltimore by Schwarz et al. (2012). The lower concentrations may be due to

369 differences in sample depth, as Schwarz et al. (2012) reported X-ray fluorescence (XRF)

370 measurements directly at the soil surface vs. samples in this study, which were collected from 0-

$37110 \mathrm{~cm}$ depth. In addition, the use of XRF technology enabled individual point measurements,

372 whereas our samples were composited per individual patch (ranged 9-300 $\mathrm{m}^{2}$ in area), which

373 may have diluted core samples that had higher concentrations. Mielke et al. (2008) compared

374 soils sampled from $0-2.5 \mathrm{~cm}$ depth in the inner core area of New Orleans with residences in

375 "outer core" areas (approximately corresponding to this studies IU and OU land-use types) and

376 found median concentrations of $\mathrm{Pb}$ between $96-152$ and $132-707 \mathrm{mg} \mathrm{kg}^{-1}$ for outer and inner core

377 areas, respectively. These values, while more comparable to this study, still had much higher

378 maximum values (over $700 \mathrm{mg} \mathrm{kg}^{-1}$ ), which were measured for individual (and not composited)

379 samples taken directly near a road or building foundation. By contrast, Mao et al. 2014

380 compared soil $\mathrm{Pb}$ concentrations among varying urban land uses along an urbanization gradient 
381 in Beijing China and found much lower urban soil concentrations (maximum of approximately

$38255 \mathrm{mg} \mathrm{kg}^{-1}$ ) than our (Table 1) or Mielke et al. (2008) results.

The source of As in residential soils of the more urbanized areas is uncertain. The concentrations of As, while elevated in the IU and S vs. the R land-use types, were not high 385 when compared to other studies. For example, Diawara, Litt, Unis, Alfonso, Martinez, Crock, 386 Smith, \& Carsella (2006) found maximum concentrations of As as high as $65 \mathrm{mg} \mathrm{kg}^{-1}$ in 387 residential communities in Pueblo, CO while Zhang (2006) found maximum concentrations of 388 As at $30 \mathrm{mg} \mathrm{kg}^{-1}$ in Galway, Ireland, which in both cases were associated with either coal 389 combustion or industrial sources that were prevalent in both study areas. Alternatively, the 390 relatively high concentrations found in these studies may be the result of the method used to 391 digest soils (HF acid), which is likely to strip more metal ions from soil exchange sites and 392 minerals than the acid digest method ( $\mathrm{HCl}$ and nitric acid) used in our study. Arsenic is also 393 used in wood preservatives, which have been implicated in contaminating soils (up to $30 \mathrm{mg} \mathrm{kg}^{-}$ $394^{1}$ ) in residences having wood decks (Townsend et al. 2003). High spatial resolution sampling 395 (meters), such as that employed in Schwarz et al. (2012) for measuring surface soil Pb, would be 396 needed to spatially relate As contamination with wood decks occurring in the residential yards of 397 this study. patch types even if the uncontaminated residences in the $\mathrm{R}$ and $\mathrm{S}$ land uses were not included in 400 the statistical test (Table 2; statistical results not shown). There are two possible reasons for the 401 lack of spatial differences within the residential yards. First, the lack of a relationship with the 402 FB patch type suggests a dispersion pattern that overtops the 2-3 story building structures found 403 in the residential areas included in this study. This finding is consistent with the "aerosol 
404 hypothesis" by Cook \& Ni (2007) that indicates that relatively large aerosols will be deposited 405 near roads while relatively light particles are carried around structures by air currents. However, 406 an overall trend in soil concentrations was found between lawn and planting beds with the bed 407 soils accumulating more $\mathrm{Cd}, \mathrm{Cu}, \mathrm{Pb}$, and $\mathrm{Zn}$ than in the lawn soils (Figs 4 and 5). Closer 408 inspection of the data suggests that the planting beds near roads and foundations drove this 409 overall result although small sample sizes and a large amount of variability associated with 410 estimates of soil metal concentrations among yard patch types kept these comparisons from 411 being significant (Table 3). Other studies have found similar relationships with spatial deposition 412 patterns in urban residential yards (Mielke 1999; Schwarz et al. 2012). Second, the yard patch 413 types themselves represent differently "treated" soils from the perspective of landscape 414 maintenance practices. The patch types related to planting beds (FB, YB, RB) are typically 415 disturbed on an annual basis and may have additions of commercially available garden soil or 416 compost, which due to governmental regulations will not be contaminated with metals. The 417 addition of uncontaminated organic matter or mineral soil would thus dilute any existing 418 contamination by metals. Older pre-1940 structures had statistically higher concentrations of $\mathrm{Zn}, \mathrm{Cd}$, and $\mathrm{Pb}$ than 420 younger post-1940 structures, with $\mathrm{Cu}$ and $\mathrm{Cr}$ exhibiting a similar trend that was not statistically 421 significant at $\mathrm{P}<0.05$. These metals also exhibited differences along the urbanization gradient, 422 which was partly driven by the fact that the OU and IU residences were generally older than the 423 S and R (Figs. 2 and 3). A MIXED approach with land use and age did not show significant 424 interactions for either the lawn or yard patch data (results not shown). These results are 425 consistent with Yesilonis et al. (2008) and Schwarz et al. (2012) who showed that Pb 426 concentrations in residential soils within Baltimore were higher in yards with older structures. It 
427 is interesting that PC2, which loaded positively with Se and Ni and negatively with As, appeared

428 to separate IU (elevated $\mathrm{Se}$ and $\mathrm{Ni}$, lowered As) from R residences, while the pattern for age of

429 structure showed negative loadings (lowered Se and Ni, and elevated As) for pre - 1940

430 structures (Figs. 2 and 3). This relationship between Ni and age may be one reason Ni did not

431 differ statistically along the urbanization gradient in this study, when Ni has differed in other

432 urbanization gradient studies (e.g., Pouyat \& McDonnell 1991 in the New York City

433 metropolitan area). Moreover, Ni may be confounded by mafic parent materials occurring in the

434 Piedmont province just north and west of the metropolitan area (Pouyat et al. 2007; Pouyat et al.

435 2008). The apparent tendency for newer lots to have elevated levels of As is consistent with the

436 use of wood preservatives in wood decks, which are typically found in residential areas of

437 relatively low population densities (Townsend et al. 2003).

\subsection{Earthworm and isopod body burdens}

439 The stronger relationship between isopod metal burdens and soil concentrations than that found 440 for worms was unexpected (Table 3). We hypothesized that isopods would exhibit less of a

441 relationship with soil concentrations than earthworms due to their feeding preferences (detritus)

442 and higher mobility and thus range in which they can forage. However, earthworm burdens were

443 only statistically related to soil concentrations of $\mathrm{Pb}$, while isopod burdens were related to $\mathrm{Pb}$ in

444 addition to $\mathrm{Cr}, \mathrm{Ni}, \mathrm{Zn}$, and $\mathrm{As}$, which were all associated with IU and OU residences (Table 3).

445 In addition, we correlated soil $\mathrm{pH}$ and metal body burdens to see if metal bioavailablity may be

446 related to soil acidity and found only a significant, but weak, relationship with isopod body

447 burdens of $\mathrm{Pb}$ and $\mathrm{Cr}(\mathrm{r}=-0.432, \mathrm{p}=0.017$ and $\mathrm{r}=-0.528, \mathrm{p}=0.0027$, respectively $)$. Otherwise,

448 we do not have any definitive explanations for these results. Perhaps the extended range that

449 isopods can forage led to a greater integration of coarse and fine detritus, including contaminated 
450 particulate matter, found in residential yards and thus led to higher concentration levels. Isopods

451 are epigeic (surface dwellers) and thus were more likely than earthworms to forage outside the

452 individual patches in which they were sampled. Isopods have been shown to be good indicators

453 of heavy metal contamination both in urban (Dallinger, Berger, \& Birkel 1992) and industrial

454 (Hopkin, Hardisty, \& Martin 1986; Donker, Van Capelleveen, \& Van Straalen 1993;

455 Scharenberg \& Ebeling 1996) areas. A handful of isopod species, including those in our study

456 area, are synanthropic, occurring in every continent both in anthropogenic and natural

457 landscapes. Hopkin, Jones, \& Dietrich (1993) suggested using such cosmopolitan species as

458 "universal indicators" in pollution monitoring studies. Our results showed good agreement

459 between isopod tissue concentration and the environment, thus supporting this assertion.

460 To interpret earthworm body burden data is more problematic due to relatively low sample size,

461 and several potentially confounding factors that affect tissue metal concentration. The earthworm

462 diet consists of a mixture of soil and detritus and varies depending on species, age, and season.

463 Earthworms also can take up metals dermally through pore water (Vijver, Vink, Miermans, \&

464 Van Gestel 2003). Metal bioavailability depends on soil pH, organic matter content, iron oxide

465 and phosphate concentrations, and their interaction with each other (Ma, Edelman, Van Beersum,

466 \& Jans 1983; Pižl \& Josens 1995; Spurgeon \& Hopkin 1996; Park, Bolan, Chung, Naidu, \&

467 Megharaj 2011). Metals, such as $\mathrm{Cu}$ and $\mathrm{Zn}$ are essential micronutrients at low concentrations,

468 but can be toxic at high concentrations. Tissue concentrations of these elements are actively

469 regulated by earthworms and physiological mechanisms exist to quickly eliminate excess levels.

470 This has been demonstrated both in artificial (Lev, Matthies, Snodgrass, Casey, \& Ownby, 2010)

471 and field soils (Spurgeon \& Hopkin 1999). Such complex interactions of environmental,

472 biogeochemical, physiological, and ecological factors do not necessarily result in a simple 
473 relationship between the environment and earthworm tissue, and explain the wide range of 474 published data not only in field correlational studies (Beyer \& Cromartie 1987; Spurgeon \& 475 Hopkin, 1996; see review in Hobbelen, Koolhaas, \& van Gestel 2004), but also under highly 476 controlled laboratory experiments (see review by Nahmani et al. 2007).

477 The fact that soil organisms sampled in the IU and OU land-use types in the Baltimore-

478 Washington metropolitan area accumulated trace metals suggests the potential for trophic

479 responses, such as the bioaccumulation in birds inhabiting these areas. Roux \& Marra (2007)

480 found higher blood levels of $\mathrm{Pb}$ for adult and nestling birds in a number of the IU and OU

481 residences we sampled. This was the case not only for resident but also migratory bird species.

482 In addition, the author's found that ground foraging birds had higher blood $\mathrm{Pb}$ concentrations

483 than shrub-canopy foragers suggesting soil invertebrates were a primary means of bird blood $\mathrm{Pb}$

484 contamination. In our comparisons, relationships between body burdens and bird blood $\mathrm{Pb}$

485 levels were mixed. In the case of earthworms, the relationship was statistically significant, with

$48678 \%$ of the variance explained in the Pearson correlation (Fig. 6a). However, isopod burdens

487 were not statistically related to bird blood $\mathrm{Pb}$ due primarily to one residence where bird blood

488 concentrations were much lower than what would be expected based on soil $\mathrm{Pb}$ concentrations

489 found for the same site (Fig. 6b). Obviously, study designs with more observations, and thus

490 statistical power, than the limited observations available in this study are needed to more fully

491 assess the relationship between body burdens of soil invertebrates and bird blood, for $\mathrm{Pb}$ and

492 other metals.

\section{Conclusions}


495 This study demonstrates that differences exist in soil metal concentrations at multiple scales;

496 from both the scale of a residential yard to a metropolitan region among urban (IU, OU),

497 suburban $(\mathrm{S})$ and rural $(\mathrm{R})$ land-use types. In all cases the concentrations for $\mathrm{Cu}, \mathrm{Pb}$, and $\mathrm{Zn}$,

498 were higher in the more urbanized areas than the R or "background" concentrations expected for

499 the soils in the study area (Coastal Plain and Piedmont physiographic provinces). Elevated

500 concentrations of $\mathrm{Cu}, \mathrm{Pb}$, and $\mathrm{Zn}$ and to a lesser extent $\mathrm{As}$ and $\mathrm{Cd}$ in residences located in older

501 and more urbanized areas suggest that people living in these areas have a greater risk of exposure

502 to these metals. However, while older structures exhibited higher concentrations across the

503 urbanization gradient, in only the IU and OU residences did the concentrations exceed EPA and

504 The Netherlands standards for $\mathrm{Pb}$ (400 ppm and 90 ppm, respectively). Obviously, the overall

505 risk of human exposure to trace metals will depend on characteristics of the soil itself (e.g., $\mathrm{pH}$,

506 P, organic matter content, and the concentration of iron oxides) and the juxtaposition of human

507 activities with soil accumulations of metals. Whatever the case, the fact that $\mathrm{Pb}$ contamination

508 persists in residential soils after regulatory measures to reduce $\mathrm{Pb}$ exposure took effect decades

509 ago is alarming. Moreover, the risk to wildlife, especially ground foraging birds, appears to also

510 be great given that soil invertebrates constitute a large proportion of their diet. 


\section{References}

517 Bain, D., Yesilonis, I.D., \& Pouyat, R.V. (2010). Metal concentrations in riparian sediments

518 along an urbanizing gradient. Biogeochemistry 107, 67-79.

519 Beyer, W. \& Cromartie, E. (1987). A survey of lead, copper, zinc, cadmium, chromium, arsenic

520 and selenium in earthworms and soil from diverse sites. Environmental Monitoring and

521 Assessment 8, 27-36.

522 Brazel, A., Selover, N., Vose, R., \& Heisler, G. (2000). The tale of two climates-Baltimore and

523 Phoenix urban LTER sites. Climate Research 15, 123-135.

524 Carreiro, M.M., Pouyat, R.V., \& Tripler, C. (2009). Nitrogen and carbon cycling in forests along

525 urban-rural gradients in two cities. In: McDonnell, M.J., Hahs, A., Breuste, J. (Eds.), Ecology of

526 Cities and Towns: A Comparative Approach. Cambridge: Cambridge University Press.

527 Cook, R.D. \& Ni, L.Q. (2007). Elevated soil lead: Statistical modeling and apportionment of

528 contributions from lead-based paint and leaded gasoline. Annals of Applied Statistics 1, 130-151.

529 Councell, T.B., Duckenfield, K.U., Landa, E.R., \& Callender, E. (2004). Tire-wear particles as a

530 source of zinc to the environment. Environmental Science and Technology 38, 4206-4214.

531 Crowley, W.P. \& Rhinhardt, J. (1979). U.S. Geological Survey map of Baltimore’s West

532 Quadrangle, scale 1:24,000, Maryland Geological Survey. Williams and Heintz Map

533 Corporation, Washington, DC.

534 Dallinger, R., Berger, A., \& Birkel, S. (1992). Terrestrial isopods: useful biological indicators of 535 urban metal pollution. Oecologia 89, 32-41. 
536 Dallinger, R. (1994). Invertebrate organisms as biological indicators of trace metal pollution.

537 Applied Biochemistry and Biotechnology 48, 27-31.

538 Diawara, M.M., Litt, J.S., Unis, D., Alfonso, N., Martinez, L., Crock, J.G., Smith, D.B., \&

539 Carsella, J. (2006). Arsenic, lead, and mercury in surface soils, Pueblo, Colorado: implications

540 for population health risk. Environmental Geochemistry and Health 28, 297-315.

541 Datko-Williams, L., Wilkie, A., Richmond-Bryant, J. (2014). Analysis of U.S. soil lead (Pb)

542 studies from 1970 to 2012. Science of the Total Environment 468-469, 854-863.

543 Donker, M.H., Van Capelleveen, H.E., \& Van Straalen, N.M. (1993). Metal contamination

544 affects size-structure and life-history dynamics in isopod field populations. In: Dallinger, R.,

545 Rainbow, P.S. (Eds.), Ecotoxicology of Metals in Invertebrates (pp. 383-399). Boca Raton:

546 Lewis Publishers.

547 Evans, C., Abrams, E., Reitsma, R., Roux, K., Salmonsen, L., \& Marra, P.P. (2005). The 548 neighborhood nestwatch program: participant outcomes of a citizen-science ecological research 549 project. Conservation Biology 19, 589-594.

550 Govil, P.K., Reddy, G.L.N., \& Krishna, A.K. (2001). Contamination of soil due to heavy metals 551 in the Patancheru industrial development area, Andhra Pradesh, India. Environmental Geology 552 41, 461-469.

553 Hjortenkrans, D., Bergback, B., \& Haggerud, A. (2006). New metal emission patterns in road 554 traffic environments. Environmental Monitoring and Assessment 117, 85-98. 
555 Hobbelen, P.H.F., Koolhaas, J.E., \& van Gestel, C.A.M. (2004). Risk assessment of heavy metal 556 pollution for detritivores in floodplain soils in the Biebosch, the Netherlands, taking

557 bioavailability into account. Environmental Pollution 129, 409-419.

558 Hopkin S.P. \& Martin, M.H. (1985). Assimilation of zinc, cadmium, lead, copper, and iron by 559 the spider Dysdera crocata, a predator of woodlice. Bulletin Environmental Contamination and 560 Toxicology 34, 183-187.

561 Hopkin, S.P., Hardisty, G.N., \& Martin, M.H. (1986). The woodlouse Porcellio scaber as a 562 "biological indicator" of zinc, cadmium, lead and copper pollution. Environmental Pollution 11, $563 \quad 271-290$.

564 Hopkin, S.P., Jones, D.T., \& Dietrich, D. (1993). The isopod Porcellio scaber as a monitor of the 565 bioavailability of metals in terrestrial ecosystems towards a global "woodlouse watch" scheme. 566 The Science of the Total Environment Supplement, 357-365.

567 Inman, J.C. \& Parker, G.R. (1978). Decomposition and heavy metal dynamics of forest litter in 568 northwestern Indiana. Environmental Pollution 17, 34-51.

569 Kaminski, M.D. \& Landsberger, S. (2000). Heavy metals in urban soils of East St. Louis, IL, 570 part I: Total concentration of heavy metals in soils. Journal of the Air and Waste Management 571 Association 50, 1667-1679.

572 Kamitani, T. \& Kaneko, N. (2007). Species-specific heavy metal accumulation patterns of 573 earthworms on a floodplain in Japan. Ecotoxicology and Environmental Safety 66, 82-91. 
574 Kay, R.T., Arnold, T.L., Cannon, W.F., \& Graham, D. (2008). Concentrations of polycyclic

575 aromatic hydrocarbons and inorganic constituents in ambient surface soils, Chicago, Illinois:

576 2001-2002. Soil and Sediment Contamination 17, 221-236.

577 Lev, S.M., Matthies, N., Snodgrass, J.W., Casey, R.E., \& Ownby, D.R. (2010). Effects of Zinc

578 exposure on earthworms, Lumbricus terrestris, in artificial soil. Bulletin of Environmental

579 Contamination and Toxicology 84, 687-691

580 Luo, X, Yu, S. Zhu, Y., \& Li, X. (2012). Trace metal contamination in urban soils of China.

581 Science of the Total Environment 421-422, 17-30.

582 Ma, W.-C., Edelman, T., Van Beersum, \& I., Jans T. (1983). Uptake of cadmium, zinc, lead, and 583 copper by earthworms near a zinc-smelting complex: influence of soil $\mathrm{pH}$ and organic matter.

584 Bulletin of Environmental Contamination and Toxicology 30, 424-427.

585 Maerz, J.C., Karuzas, J.M., Madison, D.M., \& Blossey, B. (2005), Introduced invertebrates are 586 important prey for a generalist predator. Diversity and Distributions, 11, 83-90.

587 Manta, D.S., Angelone, M., Bellanca, A., Neri, R., \& Sprovieri, M. (2002). Heavy metals in 588 urban soils: a case study from the city of Palermo (Sicily), Italy. Science of the Total

589 Environment 300, 229-243.

590 Mao, Q., Huang, G., Ma, K., \& Sun, Z. ( 2014). Variations of soil lead in different land uses 591 along the urbanization gradient in the Beijing metropolitan area. International Journal of 592 Environmental Research and Public Health, 11, 3199-3214.

593 Mielke, H.W. 1999. Lead in the inner cities. American Scientist 87, 62-73. 
594 Mielke, H.W., Gonzales, C., Powell, \& E., Mielke, P.W. Jr. (2008). Urban soil-lead (Pb)

595 footprint: retrospective comparison of public and private properties in New Orleans.

596 Environmental Geochemical Health 30, 231-242.

597 Nahmani, J., Lavelle, P. (2002). Effects of heavy metal pollution on soil macrofauna in a 598 grassland of Northern France. European Journal of Soil Biology 38, 297-300.

599 Nahmani J., Hodson M.E., \& Black, S. (2007). A review of studies performed to assess metal 600 uptake by earthworms. Environmental Pollution 145, 402-424.

601 Nowak, D.J. \& Greenfield, E.J. (2009). Urban and community forests of the Southern Atlantic 602 region: Delaware, District of Columbia, Florida, Georgia, Maryland, North Carolina, South 603 Carolina, Virginia, West Virginia. U.S. Department of Agriculture, Forest Service, Northern 604 Research Station, General Technical Report NRS-50.

605 NRCS. (1976). Soil Survey of District of Columbia. USDA, Natural Resource Conservation 606 Service, Soil Survey Report. Washington, DC.

607 NRCS. (1998). Soil Survey of City of Baltimore, Maryland. Natural Resource Conservation 608 Service. Soil Survey Report. Washington, DC.

609 Odewande, A.A. \& Abimbola, A.F. (2008). Contamination indices and heavy metal 610 concentrations in urban soil of Ibadan metropolis, southwestern Nigeria. Environmental 611 Geochemistry and Health 30, 243-254.

612 Park, J.H., Bolan, N.S., Chung, J.W., Naidu, R., Megharaj, M., 2011. Environmental monitoring 613 of the role of phosphate compounds in enhancing immobilization and reducing bioavailability of 614 lead in contaminated soils. J Environ Monitor 13, 2234-2242. 
615 Pavao-Zuckerman, M.A. (2003). Soil ecology along an urban to rural gradient in the Southern 616 Appalachians. Ph.D. Dissertation, University of Georgia, Athens, Georgia.

617 Pielou, E.C. (1984). The interpretation of ecological data. New York: Wiley Interscience.

618 Pižl V. \& Josens, G. (1995). Earthworm communities along a gradient of urbanization.

619 Environmental Pollution 90, 7-14.

620 Pouyat, R.V. \& McDonnell, M.J. (1991). Heavy metal accumulation in forest soils along an

621 urban-rural gradient in southeastern New York. Water, Air, and Soil Pollution 57-58, 797-807.

622 Pouyat, R., Groffman, P., Yesilonis, I., \& Hernandez, L. (2002). Soil carbon pools and fluxes in 623 urban ecosystems. Environmental Pollution 116, S107-S118.

624 Pouyat, R.V., Yesilonis, I.D., Russell-Anelli, J., \& Neerchal, N.K. (2007). Soil chemical and 625 physical properties that differentiate urban land-use and cover types. Soil Science Society of 626 America Journal 71, 1010-1019.

627 Pouyat, R.V., Yesilonis, I.D., Szlavecz, K., Csuzdi, C., Hornung, E., Korsos, Z., Russell-Anelli, 628 J., \& Giorgio, V. (2008). Response of forest soil properties to urbanization gradients in three 629 metropolitan areas. Landscape Ecology 23, 1187-1203.

630 Raczuk, J. \& Pokora, A. (2008). Influence of traffic pollution on heavy metal content in soil and 631 earthworms (Lumbricidae). Ecological Chemistry and Engineering 15, 265-274.

632 Raw, F. (1959). Estimating earthworm populations by using formalin. Nature 21, 1661-1662. 
633 Rawlins, B.G, Lark, R.M., O’Donnell, K.E., Tie, A.M., \& Lister, T.R. (2005). The assessment of 634 point and diffuse metal pollution of soils from an urban geochemical survey of Sheffield,

635 England. Soil Use and Management 21, 353-362.

636 Reinecke A.J., Reinecke, S.A., Musibono, D.E. \& Chapman, A. (2000). The transfer of lead (Pb) 637 from earthworms to shrews (Myosorex varius). Archives of Environmental Contamination and 638 Toxicology 39, 392-397.

639 Roux, K.E. \& Marra, P.P. (2007). The presence and impact of environmental lead in passerine 640 birds along an urban to rural land use gradient. Archives of Environmental Contamination and 641 Toxicology 53, 261-268.

642 Russell-Anelli, J.M., Bryant, R., \& Galbraith, J. (1999). Evaluating the predictive properties of 643 soil survey--soil characteristics, land practices and concentration of elements. In: Kimble, J.M., 644 R.J. Ahrens, R.J., Bryant, R.B. (Eds.), Classification, Correlation, and Management of 645 Anthropogenic Soils, Proceedings--Nevada and California, September 21-October 2, 1998. 646 USDA Natural Resource Conservation Service, National Survey Center, Lincoln, Nebraska.

647 Sawicka-Kapusta, K., Zakrzewska, M., Bajorek, K., \& Gdula-Argasinska, J. (2003). Input of 648 heavy metals to the forest floor as a result of Cracow urban pollution. Environment International $64928,691-698$.

650 SAS Institute. (2003). The SAS system for Windows. Release 9.10. SAS Inst., Cary, NC.

651 Scharenberg, W. \& Ebeling, E. (1996). Distribution of heavy metals in a woodland food web.

652 Bulletin of Environmental Contamination and Toxicology 56, 389-396. 
653 Schwarz, K., Pickett, S.T.A., Lathrop, R.G., Weathers, K.C., Pouyat, R.V., \& Cadenasso, M.L.

654 (2012). The effects of the urban built environment on the spatial distribution of lead in residential 655 soils. Environmental Pollution 163, 32-39.

656 Spurgeon, D.J. \& Hopkin, S.P. (1996). Risk assessment of the threat of secondary poisoning by 657 metals to predators of earthworms in the vicinity of a primary smelting works. Science of the 658 Total Environment 187, 167-183.

659 Spurgeon, D.J., \& Hopkin, S.P. (1999) Comparison of metal accumulation and excretion kinetics 660 in earthworms (Eisenia fetida) exposed to contaminated field and laboratory soils. Applied Soil 661 Ecology 11, 227-243

662 Steiner, M., Boller, M., Schulz, T. \& Pronk, W. (2007). Modeling heavy metal fluxes into the 663 environment. Journal Environmental Monitoring 9, 847-854.

664 Stewart, L.R., Farver, J.R., Gorsevski, P.V., Miner, J.G. (2014). Spatial prediction of blood lead 665 levels in children in Toledo, OH using fuzzy sets and the site-specific IEUBK model. Applied 666 Geochemistry 45, 120-129.

667 Török J. \& Ludvig, E. (1988). Seasonal changes in foraging strategies of nesting blackbirds 668 (Turdus merula L.). Behavioral Ecology and Sociobiology 22, 329-333.

669 Townsend, T., Solo-Gabriele, J. Tolaymat, T., Stook, K., \& Hosein, N. (2003). Chromium, 670 copper, and arsenic concentrations in soil underneath CCA-treated wood structures. Soil and 671 Sediment Contamination 12, 779-798. 
672 Trippler, D.J., Schmitt, M.D.C., \& Lund, G.V. (1988). Soil lead in Minnesota. In: Davies, B.E., 673 Wixson, B.G (Eds.), Lead in Soil: Issues and Guidelines. Environmental Geochemistry and 674 Health. Science Reviews, Northwood, U.K.

675 Usher, M.B. (1976). Aggregation responses of soil arthropods in relation to the soil environment, 676 In: Anderson, J.M., Macfayden, A. (Eds.), The Role of Terrestrial and Aquatic Organisms in 677 Decomposition Processes (pp. 61-94). Oxford: Blackwell Scientific Publications.

678 United States Census Bureau. (2000).

679 http://factfinder.census.gov/faces/nav/jsf/pages/index.xhtml?_ts=440543080637 . Accessed $680 \quad 1 / 28 / 2015$

681 van Bohemen, H.D. \& Janssen Van De Laak, W.H. (2003). The influence of road infrastructure 682 and traffic on soil, water, and air quality. Environmental Management 31, 50-68.

683 Vijver, M.G., Vink, J.P.M., Miermans, C.J.H., \& Van Gestel, C.A.M. (2003). Oral sealing using 684 glue: a new method to distinguish between intestinal and dermal uptake of metals in earthworms. 685 Soil Biology and Biochemistry 35, 25-132.

686

687 Walsh, D.C., Chillrud, S.N., Simpson, H.J., \& Bopp, R.F. (2001). Refuse incinerator particulate 688 emissions and combustion residues for New York City during the 20th century. Environmental 689 Science and Technology 35, 2441-2447.

690 Wang, J., Ren, H., Liu, J., Yu, J., \& Zhang, X. (2006). Distribution of lead in urban soil and its 691 potential risk in Shenyang City, China. Chinese Geographical Science 16, 127-132. 
692 Watmough, S.A., Hutchinson, T.C., \& Sager, E.P.S. (1998). Changes in tree ring chemistry in 693 sugar maple (Acer saccharum) along an urban-rural gradient in southern Ontario. Environmental 694 Pollution 101, 381-390.

695 Werkenthin, M., Kluge, B., \& Wessolek, G. (2014). Metals in European roadside soils and soil 696 solution -A review. Environmental Pollution 189:98-110.

697 Wong, C.S.C., Li, X.D., \& Thornton, I. (2006). Urban environmental geochemistry of trace 698 metals. Environmental Pollution 142, 1-16.

699 Xia, X., Chen, X, Liu, R., \& Liu, H. (2011). Heavy metals in urban soils with various types of 700 land use in Beijing, China. Journal Hazardous Materials 186, 2043-2050.

701 Yesilonis, I.D., Pouyat, R.V., \& Neerchal, N.K. (2008). Spatial distribution of metals in soils in 702 Baltimore, Maryland: Role of native parent material, proximity to major roads, housing age and 703 screening guidelines. Environmental Pollution 156, 723-731.

704 Yong, R.N., Mohamed, A.M.O., \& Warkentin, B.P. (1992). Principles of Contaminant Transport 705 in Soils Elsevier, New York.

706 Zhang, C.S. (2006). Using multivariate analyses and GIS to identify pollutants and their spatial 707 patterns in urban soils in Galway, Ireland. Environmental Pollution 142, 501-511.

708 Zheng, Y.M., Chen, T.B. \& He, J.Z. (2008). Multivariate geostatistical analysis of heavy metals 709 in topsoils from Beijing, China. Journal of Soils and Sediments 8, 51-58. 
711 Table 1. Percentile concentrations $\left(\mathrm{mg} \mathrm{kg}^{-1}\right)$ of trace metal concentrations for all samples taken

712 in the study. Background concentrations for $\mathrm{Cu}, \mathrm{Cr}, \mathrm{Cd}, \mathrm{Ni}, \mathrm{Pb}$, and $\mathrm{Zn}$ from Yesilonis et al.

7132008.

714 Table 2. Mean concentrations (mg kg-1) for nine metals (elements) of 0-10 cm soil in residential

715 yards. Five patch types were distinguished. Standard error is given in parentheses. $\mathrm{N}=$ number of 716 sampled patch types. There were no statistically significant differences among patch types at $717 \quad \mathrm{P}<0.05$.

718 Table 3. Pearson correlation coefficients (r) for earthworm and isopod body burdens and soil 719 metal concentrations $(0-10 \mathrm{~cm})$ in residential yards. Soil and invertebrates were collected from 720 the same patch. Significant differences are shown in bold face. 
Table 1.

\begin{tabular}{ccccccccc}
\hline $\begin{array}{c}\text { Element } \\
\mathrm{N}\end{array}$ & $\mathrm{Cr}$ & $\mathrm{Ni}$ & $\mathrm{Cu}$ & $\mathrm{Zn}$ & $\mathrm{As}$ & $\mathrm{Se}$ & $\mathrm{Cd}$ & $\mathrm{Pb}$ \\
\hline Percentile & 107 & 107 & 107 & 107 & 107 & 107 & 107 & 107 \\
Minimum & 3.9 & 3.5 & 2.1 & 13.6 & 0.51 & 0.171 & 0.011 & 6.6 \\
10 & 5.3 & 4.8 & 3.8 & 26.6 & 1.03 & 0.263 & 0.051 & 11.1 \\
20 & 7.0 & 6.0 & 6.0 & 37.1 & 1.41 & 0.364 & 0.108 & 14.4 \\
30 & 10.1 & 6.9 & 8.4 & 46.3 & 1.61 & 0.403 & 0.129 & 19.7 \\
40 & 12.0 & 7.9 & 10.5 & 56.7 & 1.96 & 0.475 & 0.148 & 27.0 \\
50 & 13.5 & 9.7 & 13.6 & 68.5 & 2.47 & 0.522 & 0.195 & 33.8 \\
60 & 16.1 & 10.8 & 15.5 & 89.7 & 2.92 & 0.597 & 0.246 & 43.6 \\
70 & 18.5 & 12.4 & 22.0 & 108 & 3.23 & 0.669 & 0.296 & 65.5 \\
80 & 21.8 & 14.0 & 25.6 & 136 & 3.59 & 0.764 & 0.391 & 93.0 \\
90 & 28.7 & 18.5 & 32.5 & 226 & 6.38 & 0.974 & 0.656 & 351 \\
Maximum & 82.3 & 40.1 & 158 & 534 & 26.0 & 1.96 & 2.08 & 916 \\
Background & 28 & 13 & 12 & 63 & NA & NA & 0.73 & 45 \\
\hline
\end{tabular}


Table 2.

\begin{tabular}{|c|c|c|c|c|c|c|c|c|c|c|c|c|c|c|c|}
\hline \multirow[b]{2}{*}{ Label } & \multicolumn{3}{|c|}{$\begin{array}{l}\text { Foundation Bed } \\
\text { (FB) }\end{array}$} & \multicolumn{3}{|c|}{ Yard Bed (YB) } & \multicolumn{3}{|c|}{ Road Bed (RB) } & \multicolumn{3}{|c|}{ Back Lawn (BL) } & \multicolumn{3}{|c|}{ Front Lawn (FL) } \\
\hline & $\mathrm{N}$ & Mean & S.E. & $\mathrm{N}$ & Mean & S.E. & $\mathrm{N}$ & Mean & S.E. & $\mathrm{N}$ & Mean & S.E. & $\mathrm{N}$ & Mean & S.E. \\
\hline $\mathrm{Cr}$ & 22 & 18 & 3.7 & 22 & 18 & 3.0 & 23 & 16 & 3.3 & 20 & 18 & 3.9 & 20 & 18 & 3.6 \\
\hline $\mathrm{Ni}$ & 22 & 11 & 1.6 & 22 & 10 & 1.0 & 23 & 11 & 1.7 & 20 & 11 & 1.7 & 20 & 11 & 1.7 \\
\hline $\mathrm{Cu}$ & 22 & 24 & 6.8 & 22 & 18 & 2.8 & 23 & 15 & 2.1 & 20 & 17 & 3.2 & 20 & 14 & 3.4 \\
\hline $\mathrm{Zn}$ & 22 & 132 & 23 & 22 & 135 & 28 & 23 & 76 & 12 & 20 & 89 & 17 & 20 & 74 & 18 \\
\hline As & 22 & 3.8 & 1.1 & 22 & 3.7 & 0.53 & 23 & 2.3 & 0.34 & 20 & 3.2 & 0.61 & 20 & 2.7 & 0.44 \\
\hline $\mathrm{Se}$ & 22 & 0.61 & 0.074 & 22 & 0.65 & 0.08 & 23 & 0.59 & 0.073 & 20 & 0.58 & 0.063 & 20 & 0.54 & 0.064 \\
\hline $\mathrm{Cd}$ & 22 & 0.41 & 0.091 & 22 & 0.32 & 0.065 & 23 & 0.24 & 0.046 & 20 & 0.27 & 0.061 & 20 & 0.20 & 0.037 \\
\hline $\mathrm{Pb}$ & 22 & 162 & 47 & 22 & 148 & 53 & 23 & 81 & 30 & 20 & 85 & 33 & 20 & 44 & 12 \\
\hline $\mathrm{Ca}$ & 21 & 3291 & 610 & 22 & 2855 & 585 & 23 & 3410 & 1010 & 19 & 1904 & 190 & 20 & 2584 & 850 \\
\hline
\end{tabular}


Table 3.

\begin{tabular}{llrrrrrrrr}
\hline & & $\mathrm{Cr}$ & $\mathrm{Ni}$ & $\mathrm{Cu}$ & $\mathrm{Zn}$ & $\mathrm{As}$ & $\mathrm{Se}$ & $\mathrm{Cd}$ & $\mathrm{Pb}$ \\
\hline Worm & $\mathrm{r}$ & 0.37 & 0.18 & 0.07 & -0.22 & 0.08 & 0.33 & 0.05 & $\mathbf{0 . 5 2}$ \\
& $\mathrm{P}$ & 0.14 & 0.49 & 0.78 & 0.39 & 0.76 & 0.20 & 0.85 & 0.03 \\
& $\mathrm{~N}$ & 17 & 17 & 17 & 17 & 17 & 17 & 17 & 17 \\
Isopod & $\mathrm{r}$ & $\mathbf{0 . 5 5}$ & $\mathbf{0 . 4 8}$ & 0.07 & $\mathbf{0 . 4 7}$ & $\mathbf{0 . 5 9}$ & -0.11 & 0.09 & $\mathbf{0 . 7 9}$ \\
& $\mathrm{P}$ & 0.0004 & 0.003 & 0.67 & 0.003 & $<.0001$ & 0.51 & 0.59 & $<.0001$ \\
& $\mathrm{~N}$ & 38 & 38 & 38 & 38 & 38 & 38 & 38 & 38 \\
\hline
\end{tabular}

2

3

4

5

6

7

8

9

10

11

12

13

14

15 
1 Figures

2 Fig. 1 The Baltimore-Washington metropolitan area showing 23 residences that

3 were included in the study. The residential urban-rural comparisons encompassed

4 the Washington, DC and Baltimore, MD metropolitan areas and extended to Denton

5 County, MD and Westminster County, MD.

6 Fig. 2 Scatter plot of first (PC1) and second (PC2) principal components for lawn (a)

7 and bed (b) patches using land-use type symbols. Symbols represent inner-urban

8 (IU), outer-urban (OU), suburban (S), and rural (R). Data were log transformed.

$9 \quad$ Fig. 3 Scatter plot of first (PC1) and second (PC2) principal components for lawn (a)

10 and bed (b) patches using symbols for structure age categories. Symbols represent

11 new (post-1940) and old (pre-1940) structure locations. Data presented log

12 transformed.

13 Fig. 4 Mean (S.E.) concentrations of soil metals in (a) residential lawns and (b) bed

14 patches by land-use type: inner-urban (IU), outer-urban (OU), suburban (S) and rural

15 (R). For lawn and bed patches, means were computed for each residential

16 household. Different letters represent significant differences for a metal between

17 land-use types at alpha=0.05. Data were log transformed.

18 Fig. 5 Mean (S.E.) concentrations of soil metals in (a) residential lawns and (b) bed

19 patches by age of structure (pre - and post - 1940 structures). For lawns and bed

20 patches, means were computed for each residential household. Different letters 
1 represent significant differences for a metal between structure age at alpha $=0.05$.

2 Data were log transformed.

3 Fig. 6 Scatter plot of $\mathrm{Pb}$ concentrations found in bird blood, soil, and body burdens

4 in residential yards in which bird blood data were available. Statistical results

5 (Pearson correlation) for relationships between bird blood and soil $\mathrm{Pb}$

6 concentrations, and bird blood and worm body burden concentrations are shown in

7 6a; and bird blood and soil Pb concentrations and bird blood and isopod body burden

8 concentrations are shown in $6 \mathrm{~b}$. 


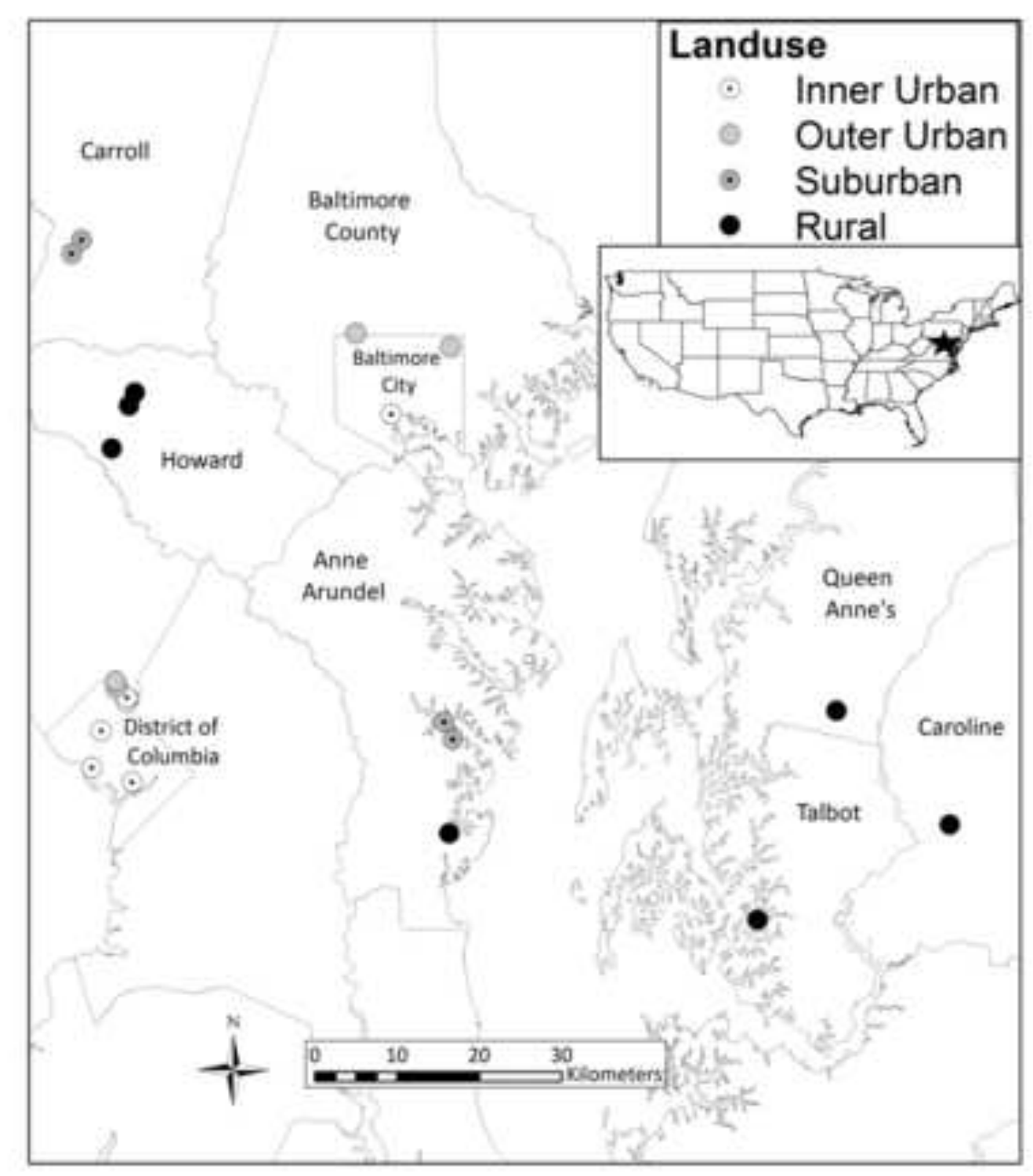


Figure 2a.
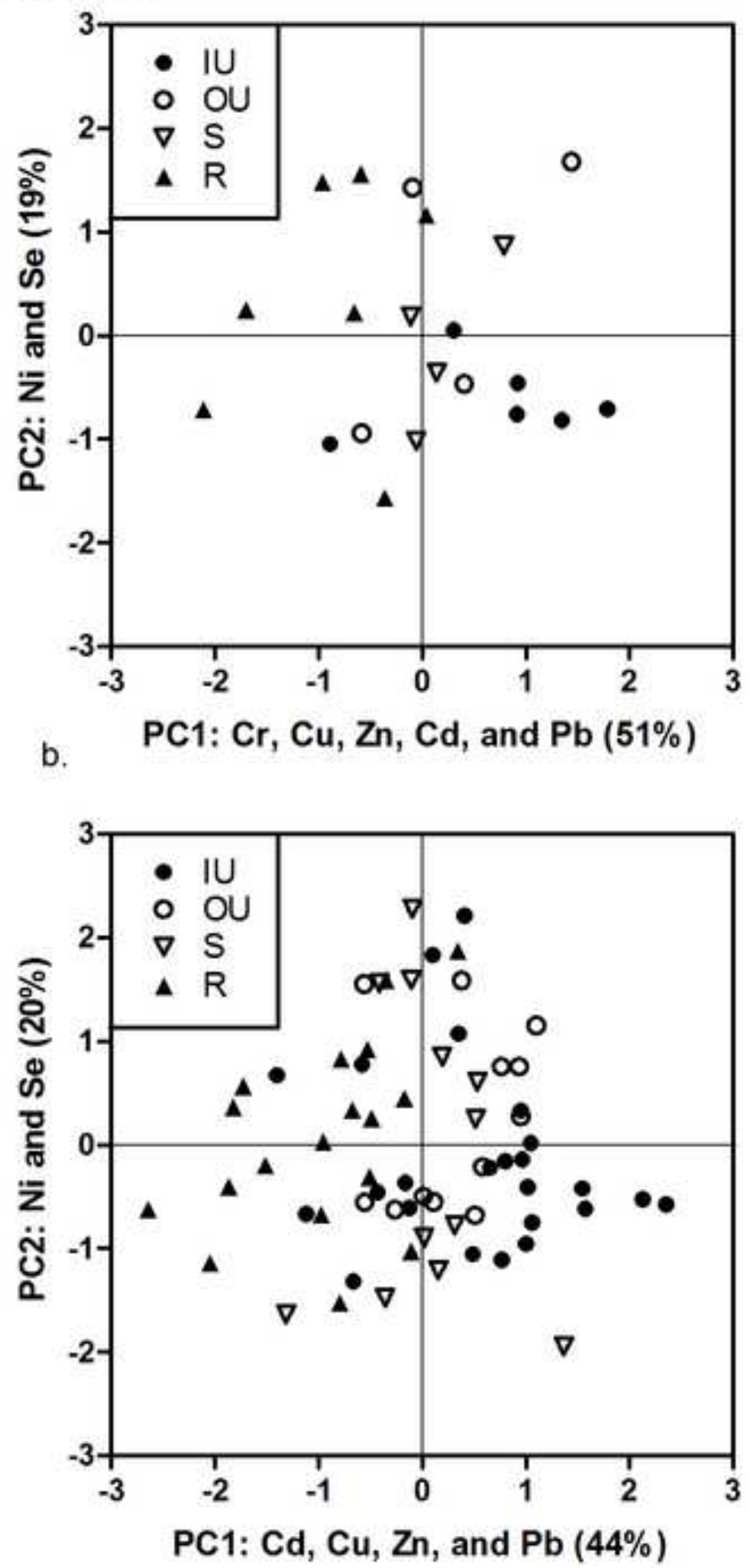
Figure $3 a$.

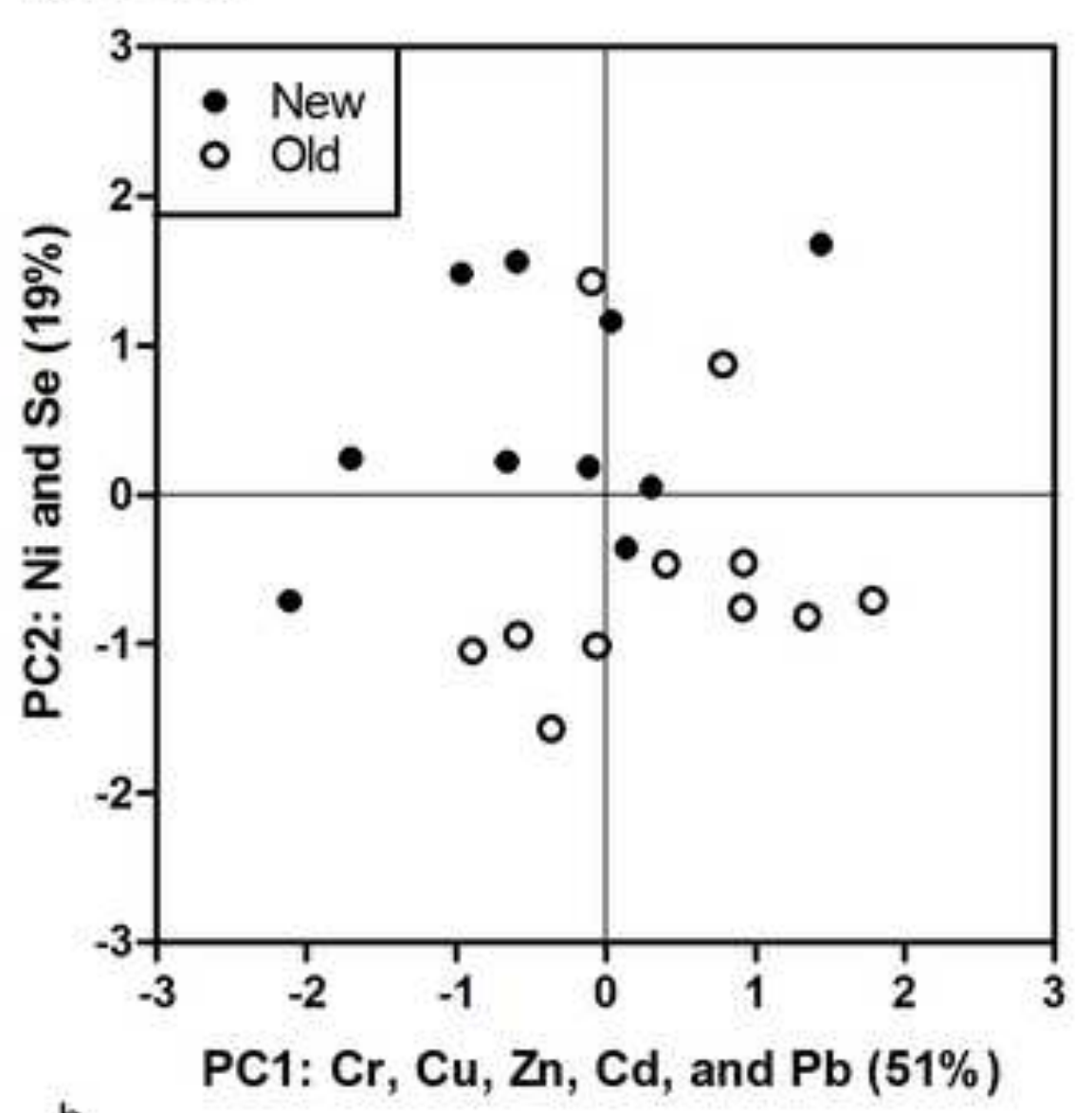

b.

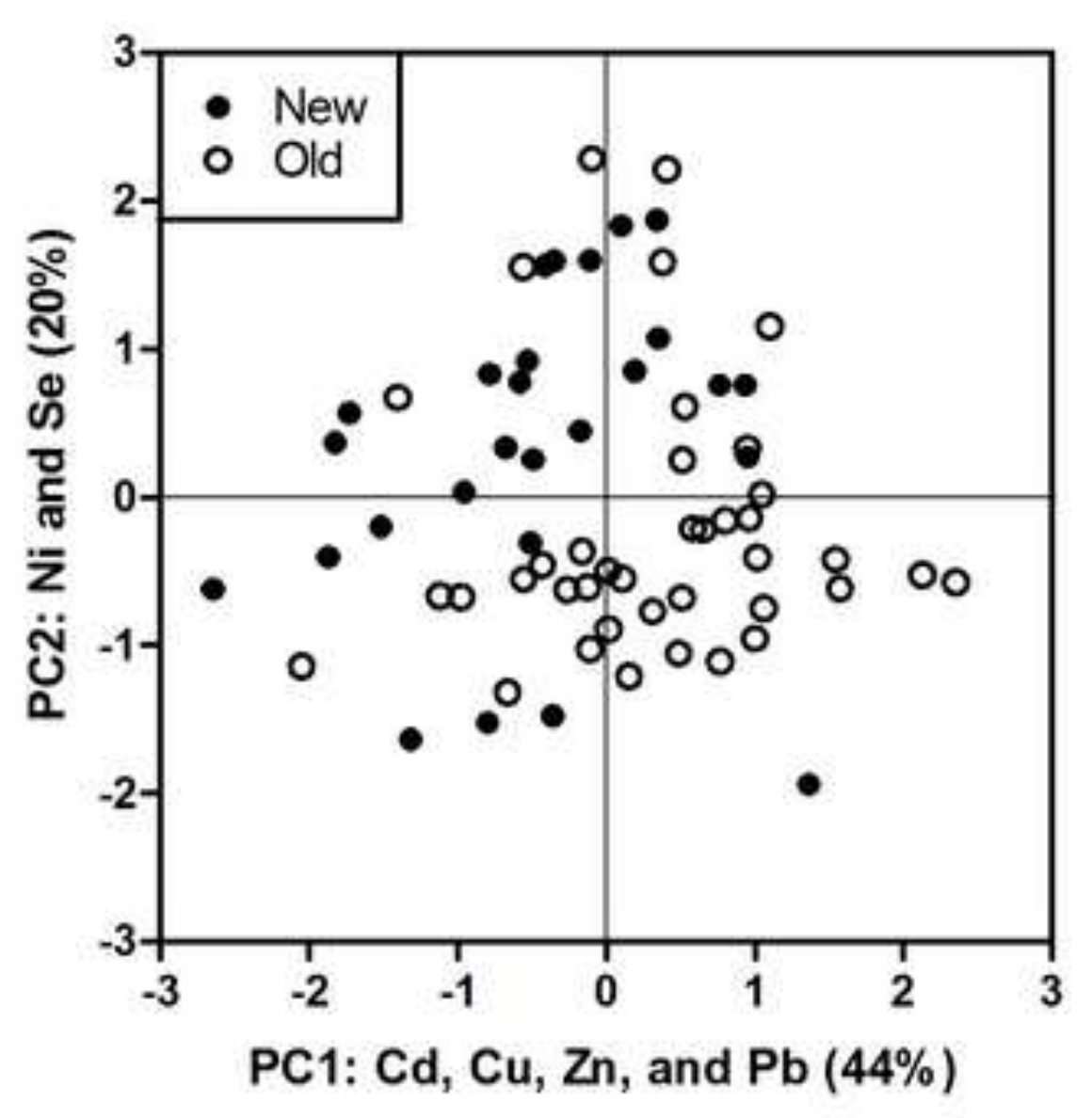


Figure 4a.

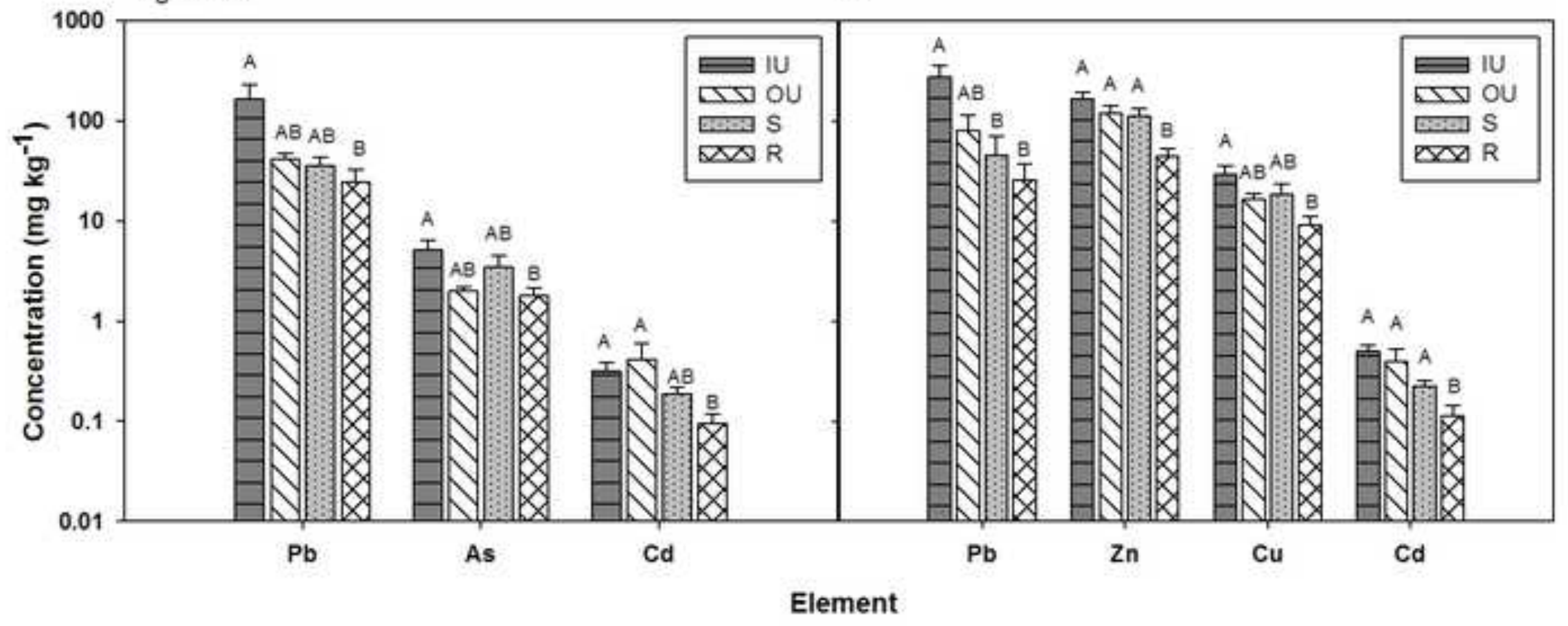


Figure $5 a$.

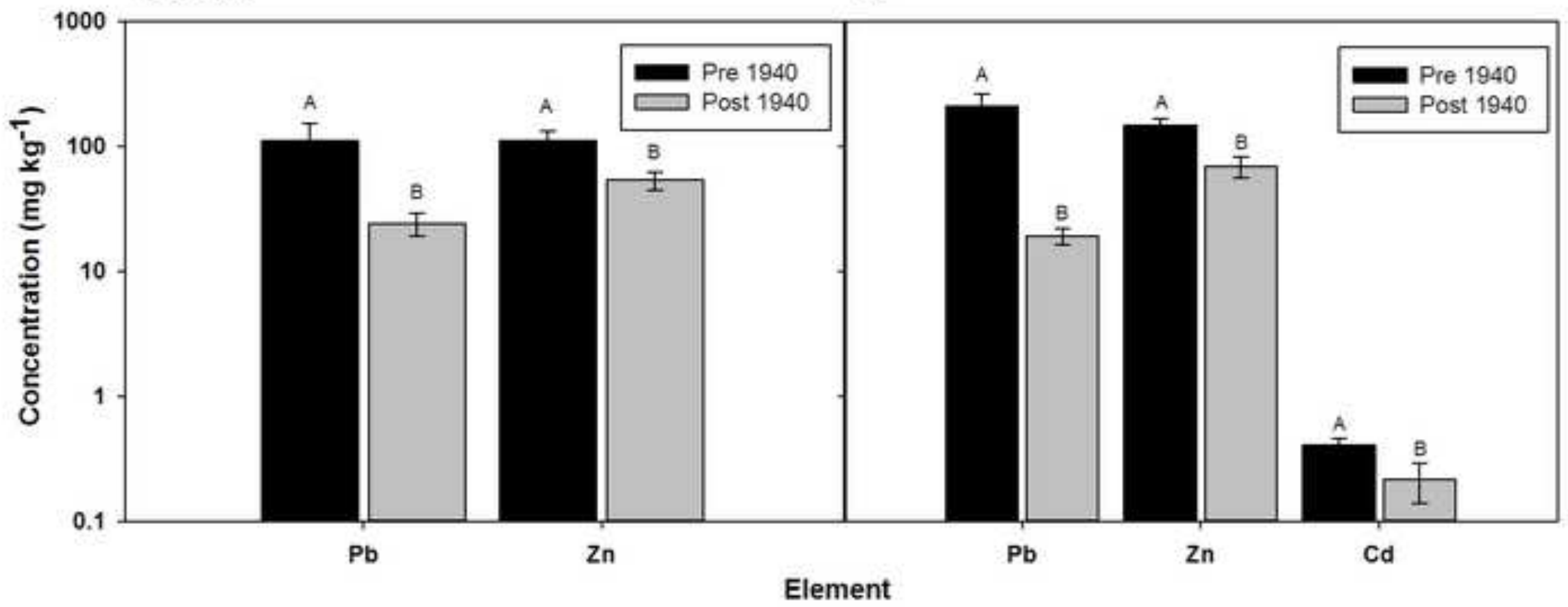


Figure 6a.

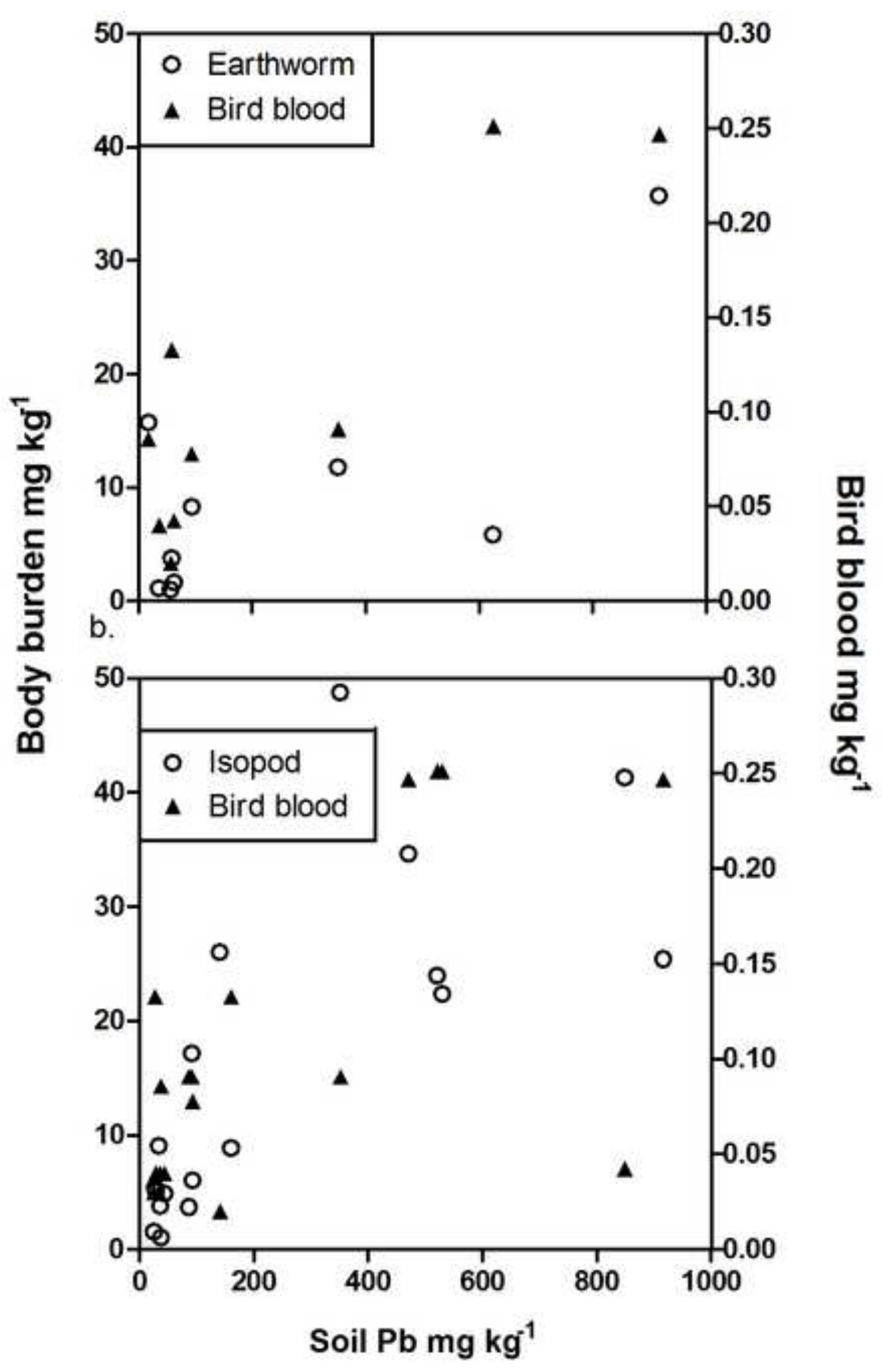

